http://dx.doi.org/10.32929/2446-8355.2021v30n2p204-215

\title{
GENETIC DIVERSITY AMONG COLORED COTTON GENOTYPES TO OBTAIN POTENTIAL PARENT PLANTS
}

Daniel Bonifácio Oliveira Cardoso ${ }^{1^{*}}$, Melissa Cristina de Carvalho Miranda ${ }^{2}$, Izabela Motta Pimentel $^{3}$, Marley Aparecida Souza Leite ${ }^{3}$, Myllena Fernandes Garcia ${ }^{3}$, Vádio Neves Belchior Júnior ${ }^{3}$, Andrezza Santos Venâncio ${ }^{3}$, Vinícius Mendes Parreira $\mathrm{Cruz}^{3}$, Arthur Prado Xavier Santos $^{3}$, Larissa Barbosa de Sousa ${ }^{4}$

\footnotetext{
${ }^{1}$ Doutorando em Agronomia, Universidade Federal de Uberlândia, Uberlândia-MG. *E-mail do autor correspondente: danieludia13@hotmail.com

${ }^{2}$ Doutoranda em Genética e Melhoramento de Plantas, ESALQ-USP, Piracicaba-SP.

${ }^{3}$ Graduando(a) em Agronomia, Universidade Federal de Uberlândia, Uberlândia-MG.

${ }^{4}$ Docente em Agronomia, Universidade Federal de Uberlândia, Uberlândia-MG.
}

Recebido: 17/04/2020; Aceito: 28/06/2021

\begin{abstract}
The objective of this study was to analyze the genetic diversity among colored cotton fiber genotypes using technological characteristics of the fiber, seed cotton yield and percentage of fiber, to identify potential parents with high performance. The experiment was conducted in the Brazilian city of Uberlândia, Minas Gerais, during the 2016/2017 harvest. Twelve colored fiber genotypes were used in a randomized block design. The characteristics that were evaluated included micronaire, maturation, fiber length, length uniformity, short fiber index, fiber resistance, elongation, seed cotton yield and percentage of fiber. Genetic divergence was estimated using the Mahalanobis generalized matrix with Unweighted Pair Group with Arithmetic Mean (UPGMA) and the Tocher method. The Singh method was used to evaluate the relative contributions of the characteristics in the divergence. In detecting divergence, fiber length and maturation were observed to have contributed the most. In order to obtain segregant populations with greater genetic variability and greater productive potential, hybridizations between UFUJP-17 and UFUJP-16 with commercial cultivars could be promising. Crossing UFUJP-16 with commercial controls would have a higher chance of success of producing superior fiber quality.
\end{abstract}

Key words: Colored fiber. Gossypium hirsutum. Genetic dissimilarity.

\section{DIVERSIDADE GENÉTICA DE GENÓTIPOS DE ALGODOEITO DE FIBRA COLORIDA PARA OBTENÇÃO DE PARENTAIS}

RESUMO: O objetivo deste trabalho foi analisar a diversidade genética entre genótipos de algodoeiro de fibra colorida utilizando características tecnológicas da fibra, produtividade e rendimento, para identificação de potenciais genitores com alto desempenho. O experimento foi conduzido no município de Uberlândia, Minas Gerais, Brasil, na safra 2016/2017. Foram utilizados 12 genótipos de fibra colorida. Avaliou-se as características micronaire, maturação, comprimento de fibra, uniformidade de comprimento, índice de fibras curtas, resistência de fibra, alongamento, produtividade e rendimento de fibra. A divergência genética foi estimada 
utilizando a matriz generalizada de Mahalanobis com agrupamento de Ligação Média entre os Grupos (UPGMA) e o método Tocher. Para avaliar as contribuições relativas das características na divergência aplicou-se o método de Singh. Observou-se que o comprimento de fibra e maturação foram aquelas que mais contribuíram para detecção da divergência. Visando obtenção de populações segregantes com maior variabilidade genética e maior potencial produtivo, hibridações entre UFUJP-17 ou UFUJP-16 com as cultivares comerciais podem ser promissoras. Cruzamentos de UFUJP-16 com as testemunhas comerciais teriam maior chance de êxito no melhoramento para obtenção de superior qualidade de fibra.

Palavras-chave: Fibra colorida. Gossypium hirsutum. Dissimilaridade genética.

\section{INTRODUCTION}

Cotton is grown in more than 60 countries in five continents, with India, China, the United States, Pakistan and Brazil being the world's top producers. In this wide diversity of environments, 52 species of cotton are registered, with Gossypium hirsutum accounting for more than $90 \%$ of the world cotton production (BORÉM; FREIRE, 2014; ASSOCIAÇÃO BRASILEIRA DOS PRODUTORES DE ALGODÃO - ABRAPA, 2021).

It is considered the most important natural textile fiber in the world, as it is used in the production of biodiesel, human and animal feed, pharmaceuticals, herbal products and oils (CRUZ et al., 2014). In the presence of several productive chains driven by the crop, colored fiber cotton has stood out considerably in recent years.

These naturally colored fibers are relevant because they reduce the amount of water used for dyeing, and in addition to lowering the production costs, this reduces the environmental pollution due to the dyes used in the process (DUTT et al., 2004).

However, cotton from colored fibers must first meet the needs of producers and subsequently the requirements of the spinning and weaving industry. At field level, cultivars must be productive, uniform in size and cycle, and resistant to major pests and diseases. For industrial purposes, the technological characteristics of the fiber are primordial factors in obtaining quality raw material from weaving. (PENNA, 2005; CUNHA NETO et al., 2015).

In genetic breeding of cotton, all these aspects must be considered. In order to reach these goals, it is necessary to carry out diversity studies among the parent plants to increase the chances of success of a breeding program (BORÉM; FREIRE, 2014; CUNHA NETO et al., 2015).

Genetic diversity is a fundamental pillar in breeding, since it provides information that identifies superior hybrid combinations with greater heterotic effect and greater heterozygosis in order to recover the superior genotypes and reach the objective of the program (CRUZ et al., 2014).

The diversity between the parents can be measured by means of biometric techniques that quantify the heterosis or by means of predictive processes. In this prediction of diversity, multivariate methods are often the most applied, with emphasis on the analysis of the main 
components, canonical variables and agglomerative methods, which stand out because they depend on previously estimated dissimilarity measurements. The Mahalanobis distance is the most used among all of them (CRUZ et al., 2014).

The general Mahalanobis distance $\left(\mathrm{D}^{2}\right)$ takes into account the correlation between the evaluated characteristics and therefore uses the means of the genotypes and the residual covariance matrix obtained in experiments with repetitions (MULATO et al., 2010; CRUZ et al., 2014).

Through the dissimilarity matrix, grouping methods in the visualization of homogeneous groups are used, with the hierarchical and optimized methods being the most common in breeding programs (FERRAUDO, 2010; CRUZ et al., 2014).

Resende et al. (2014), evaluated the genetic divergence of 248 cotton accessions, for the technological characteristics of the fiber, from the Epamig germplasm bank using the generalized Mahalanobis distance and Tocher grouping, in order to select divergent accessions based on the technological characteristics of the fiber and finding 14 different groups. Similarly, Violatti (2016) also used clustering methods while evaluating 21 cotton genotypes (G. hirsutum) based on the Mahalanobis matrix, calculated from the technological characteristics of the fiber to identify the best combinations for future hybridizations, and found 6 groups through the Tocher method. Cunha (2015), however, found greater divergence among white fiber cultivars while evaluating parents of white and colored cotton with potential for colored fiber hybrids.

Based on the above, the objective of this study was to analyze the genetic diversity among cotton fiber genotypes using technological characteristics of the fiber, productivity and yield to obtain potential parent plants.

\section{MATERIAL AND METHODS}

The experiment was conducted during the 2016/2017 harvest at the Capim Branco experimental farm (18 52' S; 48 $20^{\prime} \mathrm{W}$ and $805 \mathrm{~m}$ altitude), belonging to the Federal University of Uberlândia, in the city of Uberlândia, Minas Gerais, Brazil. The area is located on a Dark Red Latosol, with a clayey texture.

Ten cotton fiber genotypes developed by the Cotton Genetic Improvement Program (PROMALG) were evaluated, including UFUJP-01, UFUJP-02, UFUJP-05, UFUJP-08, UFUJP-09, UFUJP-10, UFUJP-11, UFUJP -13, UFUJP-16, UFUJP-17, and the commercial cultivars, BRS Ruby and BRS Topaz. The design was a randomized complete block (DBC) with four replications. The plot consisted of four lines $5 \mathrm{~m}$ in length spaced one meter apart with the area of use being the two central lines disregarding the area $0.5 \mathrm{~m}$ from each end.

The area of use of each plot was harvested and later weighed to calculate the seed cotton yield $\left(\mathrm{kg} \mathrm{ha}^{-1}\right)$, an important parameter of productivity. The seed cotton yield is the estimate obtained from the weight of seed cotton harvested in the useful area of each plot for production in 1 ha. The material was later processed to separate the fibers from the seeds and 
calculated the percentage of fibers $(\%)$, which comprises the weight of the fiber divided by the weight of the seed cotton

After the processing, the fibers were taken to the Fiber Classification laboratory in order to analyze the technological characteristics of the fibers of each plot using the HVI (High Volume Instruments) machine. The evaluated characteristics were: micronaire index, fiber maturity, fiber resistance, fiber length, length uniformity, elongation and short fibers index.

The micronaire index (MIC) is a measure of the fiber's maturity/fineness complex, and for the commercialization of the cotton, values between the limits 3.9 and 4.5 of micronaire are used, with the ideal being those values between 3.8 and 4.2 .

Fiber maturity (MAT), in turn, refers to the development of the fiber wall by the deposition of layers of cellulose.

The rupture resistance (STR), expressed in $\mathrm{gf} \mathrm{tex}^{-1}$, is determined by applying a force to distance the tweezers until the fiber bundle ruptures. Values above $26 \mathrm{gf} \mathrm{tex}^{-1}$ are considered satisfactory in the textile industry.

The length of the fiber (UHML) takes into account the average length of the longer half of the fiber bundle in 32 inch subdivisions. The length uniformity (UI) is the relation between the average length of the fibers and the UHML. The minimum value of $83 \%$ uniformity is adopted as the reference of quality.

The short fiber index (SFI) represents, as a percentage, the weight of the fibers less than $12.7 \mathrm{~mm}$ in length. The fiber elongation (ELG) refers to the maximum length reached by the fiber during a load test until it is broken. Values above $7 \%$ are considered ideal.

The data was submitted to univariate and multivariate analysis of variance using the GENES software package (CRUZ, 2013) and from this the genetic dissimilarity between the pairs of genotypes was estimated by the generalized Mahalanobis distance (D2ii') according to the following estimator:

$$
\mathrm{D}^{2}{ }_{\mathrm{ii}}^{0}=\delta^{\circ} \Psi^{-1} \delta
$$

In which:

$\mathrm{D}^{2} \mathrm{ii}^{\prime}$ : generalized Mahalanobis distance between genotypes i and i';

$\Psi$ : matrix of residual variances and covariance;

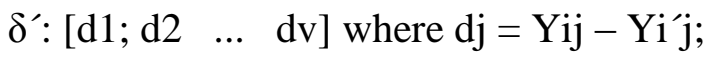

Yij: mean of the $i$-th genotype in relation to the $j$-th variable.

After obtaining the matrix of dissimilarity between genotypes, the genotypes were grouped by the hierarchical method of the Unweighted Pair Group with Arithmetic Mean (UPGMA) and Tocher's optimization (RAO, 1962).

Based on the hierarchical grouping of the Unweighted Pair Group with Arithmetic Mean (UPGMA) a dendrogram of greater similarity is generated in which the distance between the genotype and the group formed by the individuals $i$ and $j$ are given by:

$$
\mathrm{d}_{(\mathrm{ij}) \mathrm{k}}=\frac{\mathrm{d}_{\mathrm{ik}}+\mathrm{d}_{\mathrm{jk}}}{2}
$$


In addition to the dissimilarity matrix data, the Tocher optimization clustering method (RAO, 1962) was used. For this method the means of dissimilarity measurements within each group should be less than the mean distances between any groups. The inclusion or not of each genotype was determined by:

$\frac{\mathrm{d}_{(\mathrm{grupo}) \mathrm{k}}}{\mathrm{n}} \leq \theta$ Genotype $\mathrm{k}$ is included in the group;

$\frac{\mathrm{d}_{\text {(grupo)k }}}{\mathrm{n}}>\theta$ Genotype $\mathrm{k}$ is not included in the group;

In which:

$\mathrm{n}=$ number of genotypes constituting the original group.

The distance between genotype $\mathrm{k}$ and the group formed by genotypes $\mathrm{i}$ and $\mathrm{j}$ were given by:

$$
\mathrm{d}_{(\mathrm{ij}) \mathrm{k}}=\mathrm{d}_{\mathrm{ik}}+\mathrm{d}_{\mathrm{jk}}
$$

The relative contribution of the characteristics to the dissimilarity of the genotypes by the Singh method (1981) according to Sij.

$$
\mathrm{D}_{\mathrm{ii}}^{2}=\delta^{-1} \Psi^{-1} \delta=\sum_{j=1}^{n} \sum_{j=1}^{n} \omega_{i j}{ }_{j} d_{j} d_{j}
$$

In which:

$\omega_{\mathrm{j} j}=$ element of the $\mathrm{j}$-th column of the inverse of the residual variance covariance matrix.

The analyses were performed using the Statistical Program GENES (CRUZ, 2016).

\section{RESULTS AND DISCUSSION}

Significant differences were detected by the $\mathrm{F}$ test for all characteristics, indicating genetic divergence between genotypes, except micronaire (MIC) and length uniformity (IU) (Table 1).

The coefficient of variation is considered low and acceptable for most of the characteristics, between 0.88 to $10.67 \%$, except for short fiber index and seed cotton yield that are considered average, between 10.67 and 23.63 (SANTOS, 1998). These results are considered satisfactory, and therefore reliable, since seed cotton yield is a quantitative characteristic and very influenced by the environment. The results of technological characteristics of the fiber corroborate with Gama et al. (2017), who found values between 1.04 and $8.39 \%$ when analyzing the effect of silicon on fiber quality. For seed cotton yield, Queiroz (2017) found a CV value for seed cotton yield of $20.51 \%$, agreeing with this study, reinforcing the quantitative character of the characteristic. 
Table 1. Significance of the mean squares and percentage coefficients of the experimental variation for the 9 characteristics evaluated, in 12 genotypes of cotton in the 2016/17 crop. Uberlândia, Minas Gerais, Brazil.

\begin{tabular}{ccccccccccc}
\hline FV & GL & MIC & MAT & UHML & UI & SFI & STR & ELQ & SCY & PF \\
\hline Bl & 2.00 & 0.01 & 0.00 & 0.41 & 0.46 & 2.53 & 1.48 & 0.49 & 214170.64 & 0.51 \\
Gen & 11.00 & $0.04^{\mathrm{ns}}$ & $0.00^{*}$ & $10.38^{* *}$ & $4.71^{\mathrm{ns}}$ & $11.89^{* *}$ & $15.44 * *$ & $1.32^{* *}$ & $10822183.00 * *$ & $8.98^{*}$ \\
Res & 22.00 & 0.03 & 0.00 & 1.45 & 2.98 & 2.67 & 2.63 & 0.39 & 276414.17 & 3.32 \\
$\mathrm{CV}(\%)$ & - & 7.97 & 0.88 & 4.79 & 2.24 & 10.67 & 7.14 & 7.66 & 23.63 & 6.47 \\
$\mathrm{~h}^{2}$ & - & 18.00 & 63.05 & 86.01 & 36.60 & 77.52 & 82.92 & 70.08 & 74.45 & 62.96
\end{tabular}

Note: ****: Significant at 1 and 5\% probability, respectively, by the test f; ns: Not significant; FV: Sources of variation; GL: degrees of freedom; MIC: micronaire; MAT: maturation; UHML: fiber length; UI: fiber uniformity; SFI: short fiber index; STR: fiber resistance; ELG: Elongation; SCY: seed cotton yield; PF: percentage of fiber; Bl: blocks; Gen: genotypes; Res: residue; CV: coefficient of variation; $\mathrm{h}^{2}$ : coefficient of genotypic determination.

Source: Own authorship.

For the averages of the characteristics (Table 2), there was no formation of groups for micronaire, which may be justified by the low variation of MAT, which directly influences the MIC values, since MAT is calculated by the deposition of cellulose layers in the fiber, which directly affects the fineness and consequently the MIC. In general, MAT values are within ideal values for growth, which requires parameters of above 0.76 to 0.84 (BELTRÃO et al., 2004). Carvalho et al. (2015) found MAT values between 0.81 and 0.87 .

Table 2. Mean of nine morphological cotton characteristics of 12 color fiber genotypes grown in Uberlândia, Minas Gerais, Brazil.

\begin{tabular}{cccccccccc}
\hline Gen & MIC & MAT & UHML & UI & SFI & STR & ELG & SCY & PF \\
\hline G1 & $2.22 \mathrm{a}$ & $0.79 \mathrm{~b}$ & $25.41 \mathrm{~b}$ & $79.33 \mathrm{a}$ & $13.18 \mathrm{~b}$ & $23.00 \mathrm{~b}$ & $8.17 \mathrm{~b}$ & $2628.56 \mathrm{c}$ & $28.31 \mathrm{~b}$ \\
G2 & $2.34 \mathrm{a}$ & $0.80 \mathrm{~b}$ & $24.42 \mathrm{~b}$ & $77.36 \mathrm{a}$ & $15.57 \mathrm{a}$ & $22.19 \mathrm{~b}$ & $7.43 \mathrm{~b}$ & $2069.73 \mathrm{c}$ & $26.73 \mathrm{~b}$ \\
G5 & $2.46 \mathrm{a}$ & $0.79 \mathrm{~b}$ & $23.47 \mathrm{~b}$ & $76.35 \mathrm{a}$ & $17.94 \mathrm{a}$ & $20.48 \mathrm{~b}$ & $9.14 \mathrm{a}$ & $2496.26 \mathrm{c}$ & $28.15 \mathrm{~b}$ \\
G8 & $2.48 \mathrm{a}$ & $0.80 \mathrm{~b}$ & $23.07 \mathrm{~b}$ & $76.70 \mathrm{a}$ & $17.61 \mathrm{a}$ & $20.32 \mathrm{~b}$ & $8.95 \mathrm{a}$ & $2295.79 \mathrm{c}$ & $27.54 \mathrm{~b}$ \\
G9 & $2.63 \mathrm{a}$ & $0.80 \mathrm{~b}$ & $23.82 \mathrm{~b}$ & $76.22 \mathrm{a}$ & $16.25 \mathrm{a}$ & $21.64 \mathrm{~b}$ & $9.15 \mathrm{a}$ & $2778.33 \mathrm{c}$ & $27.57 \mathrm{~b}$ \\
G10 & $2.39 \mathrm{a}$ & $0.80 \mathrm{~b}$ & $25.61 \mathrm{~b}$ & $76.09 \mathrm{a}$ & $15.97 \mathrm{a}$ & $23.13 \mathrm{~b}$ & $7.70 \mathrm{~b}$ & $2231.53 \mathrm{c}$ & $27.83 \mathrm{~b}$ \\
G11 & $2.44 \mathrm{a}$ & $0.80 \mathrm{~b}$ & $24.36 \mathrm{~b}$ & $77.00 \mathrm{a}$ & $15.74 \mathrm{a}$ & $20.43 \mathrm{~b}$ & $8.79 \mathrm{a}$ & $2350.44 \mathrm{c}$ & $26.58 \mathrm{~b}$ \\
G13 & $2.34 \mathrm{a}$ & $0.80 \mathrm{~b}$ & $24.92 \mathrm{~b}$ & $76.14 \mathrm{a}$ & $14.71 \mathrm{a}$ & $23.79 \mathrm{~b}$ & $7.66 \mathrm{~b}$ & $2499.31 \mathrm{c}$ & $28.44 \mathrm{~b}$ \\
G16 & $2.49 \mathrm{a}$ & $0.80 \mathrm{~b}$ & $25.15 \mathrm{~b}$ & $75.60 \mathrm{a}$ & $14.88 \mathrm{a}$ & $22.68 \mathrm{~b}$ & $8.15 \mathrm{~b}$ & $2969.48 \mathrm{c}$ & $28.78 \mathrm{~b}$ \\
G17 & $2.44 \mathrm{a}$ & $0.80 \mathrm{~b}$ & $24.21 \mathrm{~b}$ & $75.16 \mathrm{a}$ & $17.57 \mathrm{a}$ & $21.18 \mathrm{~b}$ & $8.36 \mathrm{a}$ & $3310.48 \mathrm{~b}$ & $25.54 \mathrm{~b}$ \\
RC & $2.66 \mathrm{a}$ & $0.81 \mathrm{a}$ & $28.21 \mathrm{a}$ & $78.86 \mathrm{a}$ & $12.57 \mathrm{~b}$ & $26.99 \mathrm{a}$ & $7.51 \mathrm{~b}$ & $4275.93 \mathrm{a}$ & $31.29 \mathrm{a}$ \\
TC & $2.56 \mathrm{a}$ & $0.81 \mathrm{a}$ & $29.33 \mathrm{a}$ & $77.68 \mathrm{a}$ & $11.82 \mathrm{~b}$ & $26.86 \mathrm{a}$ & $7.48 \mathrm{~b}$ & $2946.81 \mathrm{c}$ & $31.39 \mathrm{a}$ \\
\hline
\end{tabular}

Note: Means followed by equal letters belong to the same group by the Scott-Knott test at 5\% probability level. Gen: genotypes; MIC: micronaire; MAT: maturation; UHML: fiber length; UI: length uniformity; SFI: short fiber index; STR: fiber resistance; ELG: Elongation; SCY: seed cotton yield; PF: percentage of fiber. G1: UFUJP-01; G2: UFUJP-02; G5: UFUJP-05; G8: UFUJP-08; G9: UFUJP-09; G10: UFUJP-10; G11: UFUJP-11; G13: UFUJP-13; G16: UFUJP-16; G17: UFUJP-17; RC: BRS-RUBY; TC: BRS-TOPAZ.

Source: Own authorship. 
Although MAT values were within the standards, they did not contribute to MIC indexes, which were lower than the industry requirements (3.7 to 4.2), with genetics being the most determinant factor for this characteristic (BRADOW; DAVIDONIS, 2010). In this case, they were classified as fine $(<3.0)$. However, fibers with a low MIC value and high values of MAT, STR and ELG are of interest to the textile industry, since they will add positive values to their productivity if correctly processed.

For fiber length (UHML), breeders are looking for values of over $28 \mathrm{~mm}$. Among the genotypes evaluated, 58\% (UFUJP-02, UFUJP-05, UFUJP-08, UFUJP-09, UFUJP-11, UFUJP-13, and UFUJP16) were classified as short fibers (between 23.5 to $25.15 \mathrm{~mm}$ ) and UFUJP-01, UFUJP10 and UFUJP-16 were classified as medium fibers (25.15 to $27.94 \mathrm{~mm}$ ). Commercial genotypes were classified as long fibers (above $27.94 \mathrm{~mm}$ ).

The UHML characteristic has a direct influence on yarn twisting, increasing weaving efficiency, and increasing product quality (INSTITUTO MATO-GROSSENSE DO ALGODÃO - IMAMT, 2014). In part, these values were considered below what is desirable for the industry. This can be attributed to the nocturnal temperatures below $20^{\circ} \mathrm{C}$ (Figure 1), during the period of UHML development and formation, which occurs around 100-130 days after emergency. In this period, the minimum temperatures were always below $20^{\circ} \mathrm{C}$, and therefore the environment undermined the expression of this characteristic's maximum genetic potential (BRADOW; DAVIDONIS, 2010; YEATES et al., 2010).

There is a strong relationship between UHML and fiber resistance (STR), which is that, higher values of fiber length result in higher fiber resistance values (IMAMT, 2014). For STR, ideal values are above $27 \mathrm{gf} \mathrm{tex}^{-1}$, a value not obtained from the tested genotypes. The PROMALG genotypes were classified as weak to intermediate (20 to $25 \mathrm{gf} \mathrm{tex}^{-1}$ ) and the commercial genotypes as medium (26-28 $\mathrm{gf} \mathrm{tex}^{-1}$ ) (IMAMT, 2014). In the case of fiber resistance, low MIC values may have influenced STR values. Neto (2015) found for the same commercial genotypes values between 21.12 to $24.92 \mathrm{gf} \mathrm{tex}^{-1}$, in the identification of genotypes aiming at productivity and fiber quality.

For elongation (ELG), all genotypes were classified as very high (above 7.6\%). The higher deposition of wax on the colored fibers may impart greater values of fiber elongation. Neto (2014) found values between 3.24 to $5.60 \%$ for this characteristic.

The genotypes that had the highest yields were BRS-Ruby with $4275.93 \mathrm{~kg} \mathrm{ha}^{-1}$, followed by UFUJP-17 with $3310.48 \mathrm{~kg} \mathrm{ha}^{-1}$, which were better adapted to environmental conditions for expression of their productivity genes. BRS-Ruby also had the highest value in fiber yield (31.29\%), while UFUJP-17 produced the lowest value for this characteristic (25.54). Carvalho et al. (2015) and Neto (2015) found percentage of fiber values between 33.89 and $40.24 \%$ in general, and BRS Ruby produced 33.89 and $33.18 \%$, respectively, in these authors' experiments.

When analyzing the genetic divergence of cotton for the seven technological characteristics of the fiber, seed cotton yield and percentage of fiber, the elements that contributed most to the study of genetic divergence among the genotypes (Figure 2) were UHML, which showed greater importance (21.37\%), followed by MAT (16.10\%). When 
analyzing the cotton planting in the second crop, Gilio (2014) found fiber yield (17.86\%) as the factor that contributed the most to dissimilarity. Neto et al. (2015), observed the highest values in the contribution of the divergence to the reliability index, followed by fiber yield, with $25.55 \%$ and $15.66 \%$, respectively.

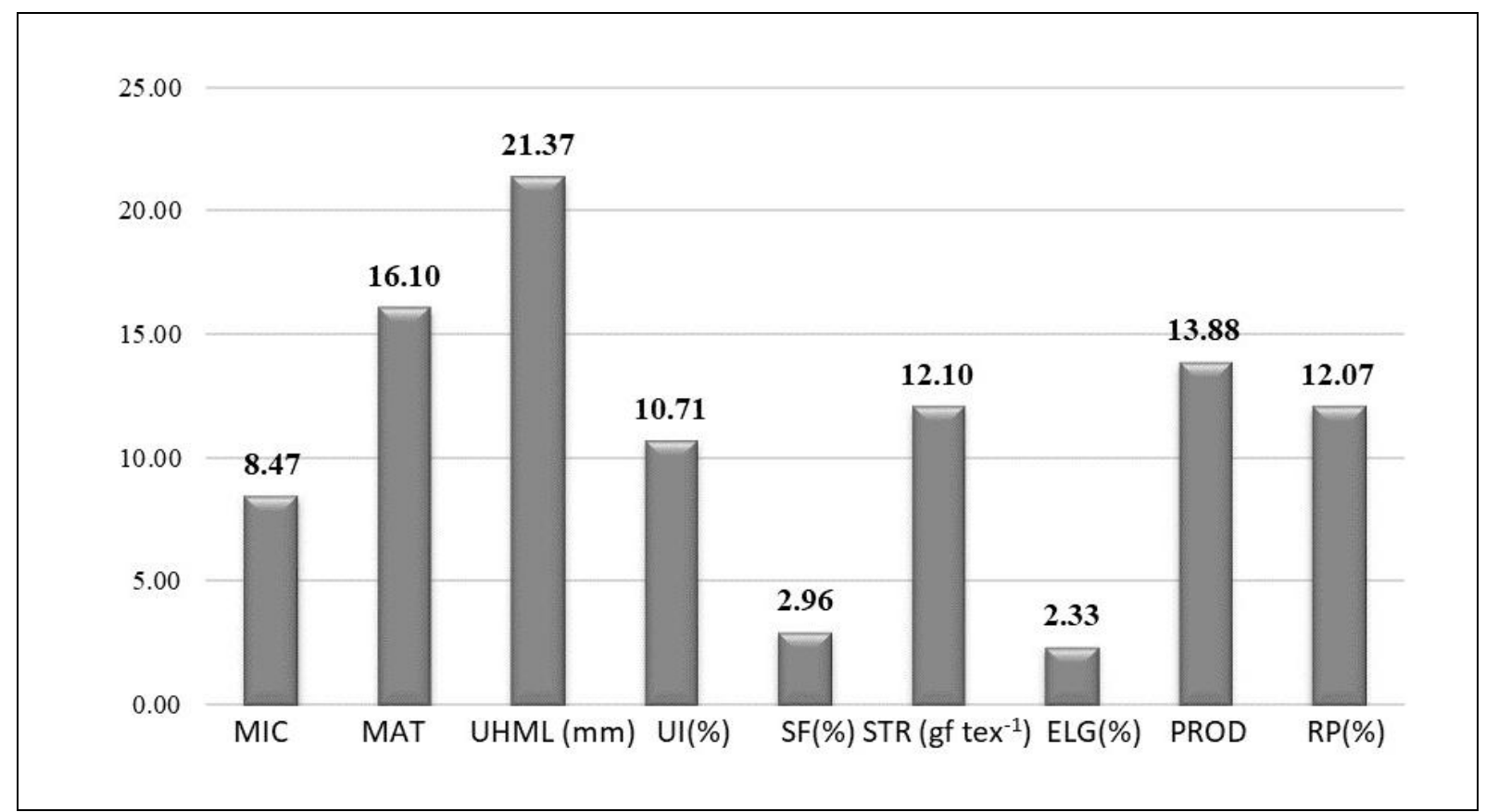

Figure 1. Relative contribution of Singh (1981) of the characteristics MIC: micronaire; MAT: maturation; UHML (cm): fiber length; UI (\%): length uniformity; SFI (\%): short fiber index; STR (gf tex $\left.{ }^{-1}\right)$ : fiber resistance; ELG (\%): Elongation; SCY $\left(\mathrm{kg} \mathrm{ha}^{-1}\right)$ : seed cotton yield; PF $(\%)$ : percentage of fiber, to quantify the divergence among 12 colored cotton genotypes.

Source: Own authorship.

Seed cotton yield was the third most important evaluation characteristic in the study, with a contribution of $13.88 \%$. This shows that the higher the productivity variation, the greater the divergence between the genotypes (SOUSA, 2013). In Figure 2 the contribution of each characteristic is shown, therefore elongation (ELG) and short fiber index (SFI) were the ones that contributed the least, exhibiting low genetic variability to these traits in the studied genotypes.

In Figure 3, with regard to the dissimilarity, the cophenetic correlation coefficient was 0.84 , which confirms the consonance of the dendrogram with the dissimilarities between the pairs of genotypes. According to Barroso and Artes (2003) coefficients above 0.70 present good representativity between the graph of the genetic distances and the matrix generated by the method. Violatti (2016) found mean values of 0.70 when analyzing the divergence of white fiber cotton genotypes. 


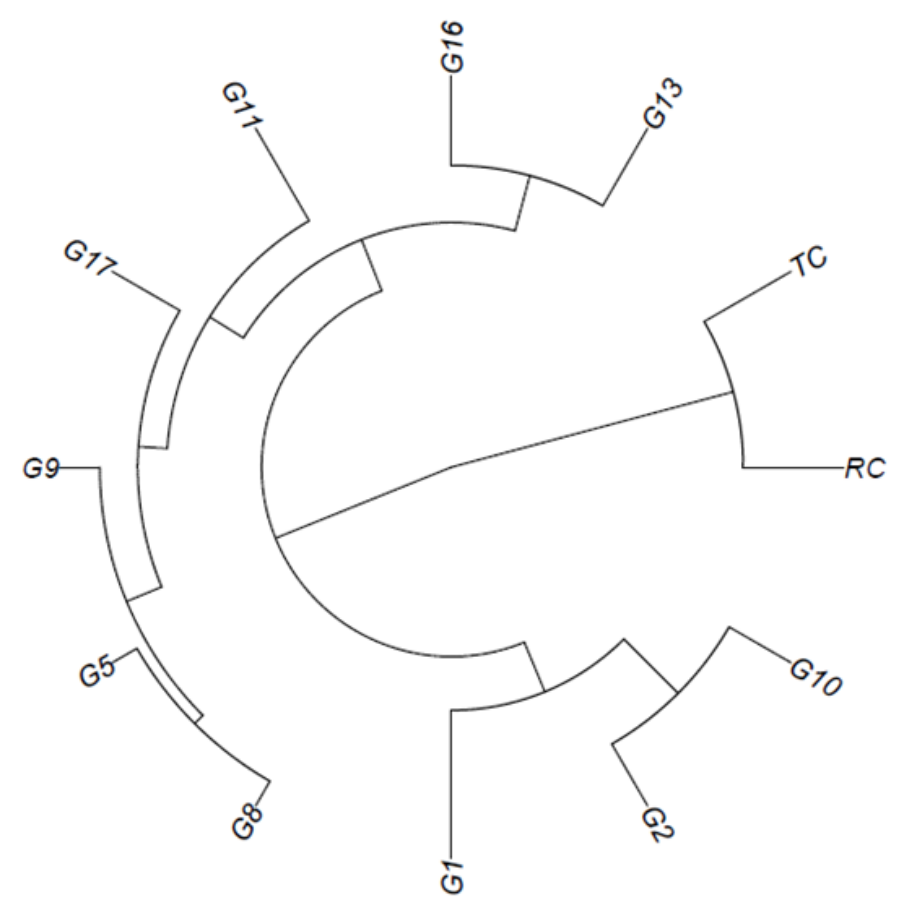

Figure 2. Dendrogram of the genetic divergence among 12 genotypes of colored fiber cotton in the 2016/2017 crop, obtained by the hierarchical middle binding method "UPGMA", based on the Mahalanobis generalized distance $\left(\mathrm{D}^{2}\right)$. Cophenetic correlation coefficient (r): 0.84 , in Uberlândia, Minas Gerais, Brazil.

Source: Own authorship.

In the graph, the cut line was established subjectively at the point of high change of level in the dendrogram (CRUZ et al., 2011), performed at 34\% dissimilarity, which separated the genotypes into 5 groups, where the commercial controls of Embrapa, were in the same group. The largest group formed (group 1) is represented by $41 \%$ of the genotypes.

The dissimilarity results of the dendrogram confirm the existence of divergence among the genotypes, demonstrating that it is possible to obtain a heterotic effect and a higher heterozygosity in possible hybridizations.

Based on the above, for a greater heterotic effect, crosses between UFUJP-05, UFUJP08, UFUJP09, UFUJP-11 and UFUJP-17 with the BRS Ruby and BRS Topaz controls, could allow individuals with higher heterosis to be obtained in the hybridizations.

The use of the UPGMA method coupled with the Tocher optimization method in dissimilarity evaluations can guarantee greater reliability in the estimation of genetic divergence (GILIO et al., 2017). Through the optimized method of Tocher (RAO, 1962) (Table 3), calculated on the basis of Mahalanobis distance ( $\left.\mathrm{D}^{2}\right), 6$ groups are formed, which is one more than the UPGMA grouping, and thus it is possible to verify the similarity in the formation of the groups, in relation to the UPGMA method. 
Table 3. Grouping of 12 color fiber cotton genotypes, using the Tocher method, using the Mahalanobis distance as a genetic distance measure, based on agronomic traits and technological characteristics of the fiber.

\begin{tabular}{ccc}
\hline Groups & $\begin{array}{c}\text { Number of } \\
\text { Genotypes }\end{array}$ & Gentoypes \\
\hline 1 & 5 & UFUJP-05, UFUJP-08, UFUJP-09, UFUJP-17, UFUJP-16 \\
2 & 2 & UFUJP-02, UFUJP-10 \\
3 & 2 & BRS-RUBI, BRS-TOPÁZIO \\
4 & 1 & UFUJP-01 \\
5 & 1 & UFUJP-13 \\
6 & 1 & UFUJP-11 \\
\hline
\end{tabular}

Source: Own authorship.

In general, the groups were similar among the methods, except for UFUJP16, UFUJP11 and UFUJP-13, where UFUJP-11 and UFUJP-13 were in the same group in UPGMA and were isolated when using Tocher, and UFUJP-16 entered the first group instead of UFUJP-11. This shows that for these analyses the Tocher method was more sensitive in determining the divergence, corroborating with Violatti (2016). However, Rocha (2015) and Giulio et al. (2017), when compared to Tocher, found greater effectiveness from the UPGMA method when assessing the genetic divergence of colored cotton.

\section{CONCLUSION}

Genetic divergence was found between the genotype of colored cotton fiber.

Hybridizations between the genotypes UFUJP-17 and BRS-Ruby or BRS-Topaz are promising for obtaining segregating populations with genetic variability and greater productive potential.

Hybridizations between UFUJP-16 and BRS Ruby or BRS Topaz genotypes are promising for obtaining progenies with superior characteristics for fiber technology.

\section{ACKNOWLEDGMENTS}

This study was financed in part by the Coordenação de Aperfeiçoamento de Pessoal de Nível Superior (CAPES) and Fundação de Amparo à Pesquisa do Estado de Minas Gerais (FAPEMIG).

\section{REFERENCES}

ASSOCIAÇÃO BRASILEIRA DOS PRODUTORES DE ALGODÃO - ABRAPA (Ed.). Consumo mundial. Available in: http://www.abrapa.com.br/Paginas/dados/algodao-nomundo.aspx. Access in: 17 jun. 2021.

BARROSO, L. P.; ARTES, R. Análise multivariada. Lavras: UFLA, 2003. 157 p. 
BELTRÃO, N. E. M.; CARVALHO, L. P. Algodão colorido no Brasil, e em particular no Nordeste e no Estado da Paraíba. Campina Grande: Embrapa Algodão-Documentos, 2004. $17 \mathrm{p}$.

BORÉM, A.; FREIRE, E. C. Algodão: do plantio a colheita. Minas Gerais: UFV, 2014. 312 p.

BRADOW, J. M.; DAVIDONIS, G. H. Effects of environment on fiber quality. In: STEWART, J. M.; OOSTERHUIS, D. M.; HEITHOLT, J. J.; MAUNEY J. R. Physiology of cotton. Dordrecht: Springer, 2010. Cap. 21, p. 229-245.

CARVALHO, L. P.; SALGADO, C. C.; FARIAS, F. J. C.; CARNEIRO, V. Q. Estabilidade e adaptabilidade de genótipos de algodão de fibra colorida quanto aos caracteres de fibra. Ciência Rural, Santa Maria, v. 45, n. 4, p.598-605, 2015.

CRUZ, C. D. Genes software: extended and integrated with the R, Matlab and Selegen. Acta Scientiarum Agronomy, Maringá, v. 38, n. 4, p.547-552, 2016.

CRUZ, C. D. Programa genes: diversidade genética. Viçosa: UFV, 2016. 278 p.

CRUZ, C. D.; FERREIRA, F. M.; PESSONI, L. A. Diversidade genética-Importância. Biometria aplicada ao estudo da diversidade genética. Viçosa: Suprema, 2011. 620 p.

CRUZ, C. D.; REGAZZI, A. J.; CARNEIRO, P. C. S. Modelos biométricos aplicados ao melhoramento genético. 4. ed. Viçosa: Editora UFV, 2014. 514 p.

DUTT, Y.; WANG, X. D.; ZHU, Y. G.; LI, Y. Y. Breeding for high yield and fibre quality in coloured cotton. Plant Breeding, Berlim, v. 123, [s.n.], p.145-151, 2004.

FERRAUDO, A. S. Técnicas de análise multivariada: uma introdução. Jaboticabal: UNESP, 2010. $77 \mathrm{p}$.

GAMA, J. S. N.; JÚNIOR, L. R. P.; PEREIRA, F.J. S.; DE OLIVEIRA, E. L.; CAMPOS, D. A.; BARROS, A. C. S. A. Efeito da adubação silicatada na qualidade da fibra do algodoeiro. Magistra, Cruz das Almas, v. 28, n. 2, p.743-752, 2017.

GILIO, T. A. S. Divergência genética em genótipos de algodoeiro e quantificação de danos causados pela mancha de ramulária. 2014. 69 f. Dissertation (Master's degree) Universidade do Estado de Mato Grosso, Tangará da Serra, 2014.

GILIO, T. A. S.; ARAÚJO, D. V.; KRAUSE, W.; ROSA, H. H. R.; ASCARI, J. P. Divergência genética em genótipos de algodão em condições de safra e safrinha. Revista Caatinga, Mossoró, v. 30, n. 2, p.377-390, 2017.

INSTITUTO MATO-GROSSENSE DO ALGODÃO - IMAMT. A classificação do algodão. cap. 15. Available in: http://www.imamt.com.br/system/anexos/arquivos/238/original/3__MANUAL_15_19.pdf?1404999627 2014. Access in: jan. 012018.

MATIELLO, R. R.; SILVA, D. F. G.; COELHO, C. J.; ROMANEK, C.; GARDINGO, J. R.; SILVA, A. R.; GRACZYKI, B. L.; OLIVEIRA, E. A. T. Dissimilaridade genética e definição de grupos de recombinação em progênies de meios-irmãos de milho-verde. Bragantia, Campinas, v. 75, n. 4, p.401-410, 2016. 
MULATO, B. M.; MÖLLER, M.; ZUCCHI, M. I.; QUECINI, V.; PINHEIRO, J. B. Genetic diversity in soybean germplasm identified by SSR and EST-SSR markers. Pesquisa Agropecuária Brasileira, Brasília, v. 45, n. 3, p.276-283, 2010.

CUNHA NETO, J. C.; MAGAlHÃES BERTINI, C. H. C.; SILVA, A. P. M. Divergência genética entre genitores de algodoeiro de fibras brancas e colorida. Revista Brasileira de Ciências Agrárias, Recife, v. 10, n. 4, p.492-498, 2015.

PENNA, J. C. V. Melhoramento do algodão. In: BORÉM A. (Ed.). Melhoramento de espécies cultivadas. 2. ed. Viçosa: UFV, 2005. Cap. 1, p. 15-53.

QUEIROZ, D. R. Análise genética para caracteres agronômicos e tecnológicos de fibra em genótipos de algodoeiro herbáceo (Gossypium hirsutum L. var. Latifolium Hutch.). 2017. 63 f. Dissertation (Master's degree) - Universidade Estadual da Paraíba, Paraíba, Brasil, 2017.

RAO, R. C. Advanced statistical methods in biometrics research. New York: John Wiley and Sons, 1962. $390 \mathrm{p}$.

RESENDE, M. A. V.; DE FREITAS, J. A.; LANZA, M. A.; RESENDE, M. V. D.; AZEVEDO, C. F. Divergência genética e índice de seleção via BLUP em acessos de algodoeiro para características tecnológicas da fibra. Pesquisa Agropecuária Tropical, Goiânia, v. 44, n. 3, p.334-340, 2014.

ROCHA, G. M. G. Diversidade genética e expressão gênica em fibras de algodão colorido. 2015. 45 f. Dissertation (Master's degree) - Universidade Estadual da Paraíba, Campina Grande, Brasil, 2015.

ROTILI, E. A.; CANCELliER, L. L.; DOTTO, M. A.; PELUZIO, J. M.; CARVALHO, E. V. Divergência genética em genótipos de milho no Estado do Tocantins. Revista Ciência Agronômica, Fortaleza, v. 43, n. 3, p.516-521, 2012.

SANTOS, J. W.; MOREIRA, J. D. A. N.; FARIAS, F. J. C.; FREIRE, E. C. Avaliação dos coeficientes de variação de algumas características da cultura do algodão: uma proposta de classificação. Revista Brasileira de Oleaginosas e Fibrosas, Campina Grande, v. 2, n. 1, p.35-40, 1998.

SIMON, G. A.; KAMADA, T.; MONTEIRO, M. Divergência genética em milho de primeira e segunda safra. Revista Semina, Londrina, v. 33, n. 2, p.449-458, 2012.

SOUSA, L. B. Diversidade fenotípica e molecular, correlações entre caracteres, adaptabilidade e estabilidade de genótipos de soja. 2013. 142 f. Thesis (Doctor's degree) Universidade Federal de Uberlândia, Uberlândia, 2013.

VIOLATTI, M. R. Qualidade da fibra e diversidade genética em algodoeiro de fibra branca. 2016. 44 f. Dissertation (Master's degree) - Universidade Federal de Uberlândia, Uberlândia, 2016.

YEATES, S. J.; CONSTABLE, G. A.; MCCUMSTIE, T. Irrigated cotton in the tropicaldry season. I: Yield, Its components and crop development. Field Crops Research, v. 116, n. 3, p.278-289, 2010. 